\title{
Mary in Jewish Tradition
}

\author{
Maria na Tradição Judaica
}

Daniel J. Lasker ${ }^{1}$

\begin{abstract}
Since Jews rejected the miraculous account of Jesus' birth, they assumed that Mary conceived through illicit sexual activity, sometimes expressed in vulgar terms. Some Jews refuted the possibility of virgin birth by use of philosophical arguments, and others offered scriptural arguments against Mary's perpetual virginity. Despite generally negative views of Mary, there is evidence of an attraction to the idea of a semi-divine female role model and it is possible that certain Kabbalistic interpretations of the divine presence have Marian overtones.
\end{abstract}

Keywords: Christianity, Jesus, Judaism, Mary, miracles, virgin birth

Resumo: Uma vez que os judeus rejeitaram o relato milagroso do nascimento de Jesus, eles assumiram que Maria era concebida através de atividade sexual ilícita, às vezes expressa em termos vulgares. Alguns judeus refutaram a possibilidade do nascimento virginal por meio de argumentos filosóficos e outros ofereceram argumentos bíblicos contra a virgindade perpétua de Maria. Apesar das opiniões geralmente negativas acerca de Maria, há evidências de uma atração pela idéia de um modelo feminino semi-divino e é possível que certas interpretações cabalísticas da presença divina tenham mapeamentos marianos.

Palavras-chave: cristianismo, Jesus, judaísmo, Maria, milagres, nascimento virginal

In the 1240 Disputation of Paris, which effectively put the Talmud on trial in anticipation of its subsequent public burning, the former Jew who initiated the debate, Nicolas Donin, cited a Talmudic passage (b. Shabb. 104b [cf. b. Sanh. 67a, in uncensored editions]) claiming that Miriam, i.e., Mary, the mother of Jesus, was unfaithful to her husband. Catholic priests reacted sharply; the Jewish account of the disputation quotes them as saying: "Why have you spoken this way about Miriam? What did she ever do to you?” This exchange encapsulates a seemingly deep and unbridgeable chasm: Christians

\footnotetext{
${ }^{1}$ Norbert Blechner Professor of Jewish Values (Emeritus). Goldstein-Goren Department of Jewish Thought, Ben-Gurion University of the Negev, P.O.B. 653, Beer Sheva, Israel.E-Mail: lasker@bgu.ac.il. Reproduzido com permissão da Oxford University Press, The Jewish Annotated New Testament, org. Amy-Jill Levine and Marc Zvi Brettler, 2nd edition, 2017, ISBN 978-0-19-046185-o, p. 744-747.
} 
regarded Mary as the perfect woman and mother of God; Jews saw her as an adulteress.

The assumption that Mary became pregnant naturally, and illicitly, has a long tradition in Jewish tradition. The New Testament does not portray Jews as explicitly questioning Jesus' paternity in the same manner as they doubt his salvific powers (Mt 27.42) or resurrection (28.11-15), and it quotes Jews referring to Jesus as the carpenter's son (Mt 13.55), Joseph's son (Lk 4.22), and Mary's son (Mk 6.2), with no assumption of sexual impropriety. According to John 8.41, however, "the Jews" (Gk: "Ioudaioi") say to Jesus, "We are not illegitimate (Gk: "ek porneias"; lit., "out of sexual immorality”) children...” This verse might hint at a charge of illegitimacy. Whether the nativity stories in Matthew and Luke were meant to deflect Jewish accusations that Jesus was conceived in a forbidden manner by asserting that he was the son of God conceived without sexual intercourse, or whether the nativity stories gave rise to the charge of illegitimacy, remains a matter of debate.

Later Jewish texts, implicitly in rabbinic literature and explicitly in the various versions of Toledot Yeshu ("The Generations of Jesus," a medieval acerbic parody on the New Testament of unclear authorship and date; see "Jesus in Medieval Jewish Tradition"), reconstruct Mary's adultery and her son's tainted paternity. The Talmud (in the passages cited above) calls the mother of Jesus "Miriam the [hair] dresser of women" (Aramaic: "Miriam megaddela [sei'ar] neshaiya"), indicating a confusion of the mother of Jesus with Mary Magdalene (this appellation appears as well in Hag. 4b, without reference to Jesus; the author may have been aware of Mary Magdalene's reputation as a prostitute).

In Toledot Yeshu, Mary's husband is named not "Joseph" but "Pappos ben Judah"; Jesus is called the "Son of Pandera", or the "Son of Stada." (The Christian scholar and theologian Origen notes that the second-century pagan writer Celsus attributes the charge of illegitimacy and the name Pandera to Jewish sources [Cels. 1.28, 32, 69]). The meaning of these names is unclear despite various conjectures, e.g., Pandera is a mocking play on the Greek "parthenos," the Gospel of Matthew's term for Mary's virginity (see Mt 1.23; Isa 7.14 LXX); Stada is a deviant women (based on the "sotah," a woman accused of adultery in Num 5). None of the conjectures is fully satisfying. Although there is an implication of impropriety in the accounts of Jesus' conception, and Talmudic references to Jesus with the different names of his father are derogatory, the details of his conception are left opaque. 
In Toledot Yeshu the accusation of adultery is unambiguous, although the specifics differ according to the work's various recensions, with discrepancies in the names of both Mary's fiancé and her paramour. The Toledot describes Mary as an engaged woman, which in Jewish law is tantamount to being married, so that intercourse with a man other than her future husband is considered adultery (e.g., b. Yev. 6gb, cf. Mt 1.19). Any child who is conceived as a result of such relations is considered a mamzer (the product of an incestuous or adulterous relation who cannot marry another Jew who is not a mamzer). Despite her engagement, Mary has sexual relations with a Roman soldier named Pandera or Joseph ben Pandera, either wittingly or in the mistaken belief that he was her fiancé. In some versions she is also in a state of menstrual impurity, in violation of Leviticus 15, adding further opprobrium to Jesus' conception.

In the popular Jewish imagination, therefore, the possibility that Mary became pregnant without normal sexual intercourse is dismissed. Yet some Jewish authors, such as the Italian scholar Abraham Farissol (ca. 1451-1525) were willing to entertain the possibility that she had become pregnant by means of a divine activity. Thus, Mary's virginity ante partum (before birth, at conception) was not rejected on the grounds that such conception is beyond the means of an omnipotent God. Even a miraculous pregnancy, however, would not mean that the child born could be God incarnate; such incarnation, either of the entire divinity or one Person of the Trinity, was disallowed for other philosophical reasons relating to God's incorporeality and immutability. Similarly, the claim of Mary's virginity post partum (after the birth of Jesus), first suggested by the second century Protevangelium of James, was excluded by the late fourteenth-century Spanish philosopher Profiat Duran and other polemicists as incompatible with New Testament verses, such as Mt 1.25, which suggest that Joseph had sexual relations with Mary after the birth of Jesus.

Rather than concentrating on Mary's virginity ante partum or post partum, Jewish polemicists, such as Duran and his contemporary Hasdai Crescas (1340-1410/11), focused on questioning claims of Mary's virginity in partu (during birth), namely, that the birth of Jesus did not cause the physical cessation of Mary's virginity. This claim had become normative Catholic belief in the Middle Ages: Mary was seen as a new Eve, just as Jesus was the new Adam (cf. Romans 5); just as Jesus redeems humanity from Adam's original sin, so Mary reverses Eve's pain in childbirth (Gen 3.16). Consequently, 
although Jesus physically passed through Mary's birth canal, this did not cause a rupture of her virginity. Further, Mary's virginity post partum would lose its significance if it were lost in partu. Christian theologians themselves discussed how it was possible for Jesus' birth to be both natural, like any other baby's, and miraculous, since it did not bring about the loss of Mary's virginity, which, in their view, was a state in which the womb was closed ("utero clauso"). Thomas Aquinas (1225-1274), for instance, posited that God can cause two bodies, namely the baby Jesus and Mary's closed womb, to coexist simultaneously in one place. Others, such as Pope Innocent III (1161-1216), suggested that Jesus had what was called a "glorious body," namely, a body that does not have standard physical properties, and hence did not cause pain or damage to his mother's closed womb, i.e., her virginity, as he passed through the birth canal.

The Jewish polemicists, including Crescas and Duran as well as others, rejected the possibilities of the interpenetrability of real bodies or of a glorified body. Although a miraculous violation of the laws of nature was theoretically possible, such as fertilization in the absence of sexual intercourse, the coexistence of two bodies in the same place and time (Jesus's body and Mary's closed womb) is logically impossible in light of the definition of what a body is. Nor did these Jewish scholars find as a satisfactory answer the "glorified body," postulated by some Christians as a solution to the simultaneous presence of Jesus' body in multiple pieces of the Eucharist, as well as to the problem of virginity in partu. If it is "glorious," it is not a body, and if it is a "body," it is not glorious, they claimed. Christians were aware of these objections to their doctrine, and, eventually, some Protestant denominations abandoned the belief in Mary's perpetual virginity. Another aspect of Roman Catholic Marian doctrine, namely that Mary was not tainted by original sin inherited from Adam because her parents produced her through a miraculous, sinless "Immaculate Conception," seems to have been unknown to Jewish authors.

Occasionally Jews mocked the figure of Mary by referring to her not as Maria, but by the rhyming Aramaic haria, an indelicate term for excrement (other insulting word plays, such as calling the apostle Peter the first-born of the ass [Heb "peter hamor"], were particularly popular in thirteenth-century north European Jewish polemics). Some eighteenth-century Italian Jews ridiculed a number of aspects of Marian devotion. Jonah Rappa (writing approximately in the second decade of the eighteenth century) provides an 
Atlas Marianus (a map of Marian shrines) as part of his mocking of Christian practices. A contemporary anonymous author records the Christian folk belief, intended, in his opinion, for weak-minded, gullible people, that Mary's home was moved many times until it ended up in Loreto in Italy, where it served as a place of pilgrimage. Some Jews also questioned the authenticity of reports that statues and portraits of Mary performed miracles.

Even before these Jewish responses to Mary and Marian devotion, some Christians had accused Jews of poor treatment of Mary, such as putative Jewish interference in her "dormition" (death and bodily ascent to heaven), accounts of which date from the fifth or sixth centuries. Building upon these earlier anti-Jewish narratives, medieval Christians saw Jews, despite their powerlessness, as oppressors not only of Jesus but also of his mother. This explains why a number of Christian texts, such as Marian miracula collections that recount miracles performed by Mary and that began circulating in Europe from the twelfth century, and artistic sources, such as the thirteenth-century illustrated Cantigas de Santa Maria, portray Mary as protecting Jewish converts to Christianity from their former co-religionists who wished to punish those they saw as apostates. In some narratives, Mary's intercession is related to alleged Jewish attempts at desecrating the host (the wafer of the Eucharist), meaning she was also defending what Christians believed is her son's body. Alternately, a number of medieval Christians report that in the moments of great pain, some birthing Jewish women would call out to Mary for protection or even actually converted upon beholding a revelation of Mary during labor.

As Christians incorporated more acts of devotion to Mary as part of their normative practices, Jews reacted in a different ways. Some engaged in polemic; others developed within Judaism a semi-divine female role model with Marian overtones. This can be seen in a number of different contexts. One of these is a salvific role assigned to the mother of the Jewish messiah. The seventh-century Apocalypse of Zerubbavel, written in the Land of Israel under Byzantine control, depicts the mother of the Messiah's arch-enemy (an Anti-Christ figure named Armilus) as a virgin, albeit made of stone and impregnated by Satan (and, thus, an Anti-Mary), while portraying the Messiah's mother, Hefzibah, as joining her son in fighting his enemies and resurrecting the fallen Messiah son of Joseph.

A more significant and lasting Jewish innovation, possibly influenced by Marian devotion, is the Kabbalistic transformation of the Shekhinah, the 
divine presence, into the female aspect of divinity. In rabbinic literature, the Shekhinah is the indwelling or manifestation of God (see e.g., b. Baba Batra 25a; b. Sanh. 39a), but it has little or no female connotation despite the word's feminine grammatical form. By the thirteenth century, however, the Shekhinah is identified in the Kabbalah with the last of ten divine realms, known as Sefirot, into which the Godhead is divided (the Sefirot also may have Christian antecedents in Trinitarian doctrine). The Shekhinah's characteristics are decidedly female: mother, nurturer, lover of male aspects of the Godhead, and the like.

A number of the descriptions of the Shekhinah, especially in the late thirteenth-century Zohar, composed in Spain, may have direct parallels in Western European Christian commentaries on the Song of Solomon, such as those of Bernard of Clairvaux (1090-1153) and Honorius Augustodinensis (1090-1156). In this Christian exegesis, the female protagonist of the Song is interpreted as Mary and her beloved as Jesus, who functioned as both her son and her lover. Although there is no direct evidence of Christian influence on this development in Kabbalah, the chronological and geographical proximity between the two sets of beliefs likely rule out pure coincidence. Similarly, the importance the Kabbalah assigns to the demonic figures Samael and Lilith may reflect polemics against their possible stand-ins, Jesus and Mary.

Medieval Jewish art also evinces a Jewish appropriation of Marian imagery. As Christians began interpreting the Song of Solomon as a love poem between Jesus and Mary, they produced artistic representations of Mary as a bride symbolizing the Church (ecclesia), often as triumphant over a vanquished synagogue (synagoga). A number of Jewish artists then adapted Christian images in their manuscript illuminations of religious poetry based on the Jewish interpretation of the Song symbolizing the relation between God and Israel. Medieval Hebrew codices contain illustrations of brides and grooms that are mirror images of Christian representations of Mary and Jesus, with similarities in dress and posture.

An additional Marian influence seems to be connected to another woman who shares Mary's name: Miriam, sister of Moses and Aaron. Jewish tradition connects the death of Miriam and the immediate need for water in the desert (Numbers 20), and it postulates a special well that accompanied the Children of Israel as long as Miriam was alive. As medieval Jews searched for a nurturing female prototype, perhaps in competition with the Christian Mary, Miriam came to play that role, and various ritual practices concerning 
water were associated with her. Judah the Pious (1150-1217) even attributed to Miriam an expiatory function in his Book of Gematriyot, parallel to Christian beliefs about Mary.

An examination of Jewish reactions to Mary reveals a combination of repulsion because of the crimes against Jews committed in her name and in the name of her son, such as massacres, expulsions, forced conversions, discrimination, pillaging, etc., but also a kind of fascination with the positive aspects of her character as understood by the Jews' Christian neighbors. That fascination may very well have been appropriated by Jews in subtle and diverse ways.

\section{References}

Standard translations were used for Hebrew and Greek Scriptures.

Herford, R. Travers. Christianity in Talmud and Midrash. New York: Forgotten Books, 2012.

Lasker, Daniel J. Jewish Philosophical Polemics Against Christianity in the Middle Ages, 2nd ed., Oxford University Press, 2007, pp. 153-159.

Shoham-Steiner, Ephraim. "The Virgin Mary, Miriam, and Jewish Reactions to Marian Devotion in the High Middle Ages," AJS Review 37:1 (April 2013): 75-91.

The Talmud: The Steinsaltz Edition. New York: Random House, 1989.

The William Davidson Talmud online at Sefaria. Available at: <https://www.sefaria.org/texts/Talmud>

Toledot Yeshu, In: Michael Meerson and Peter Schäfer, Toledot Yeshu. The Life Story of Jesus, 2 vols., Tübingen, 2014.

Data de recebimento: 11/01/2018

Data de aceite : 10/03/2018 